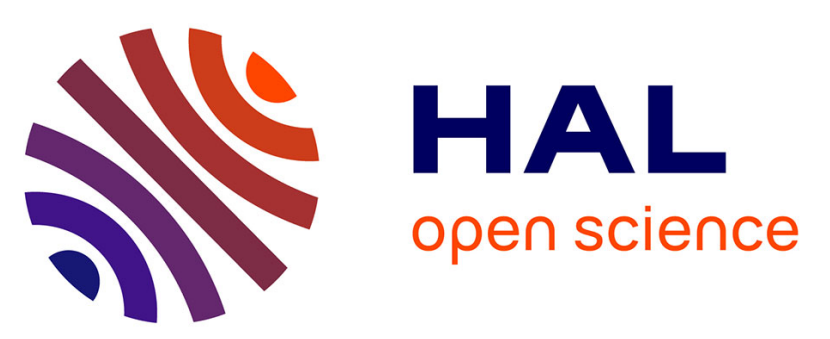

\title{
Development of the PC-GMAW welding technology for TMCP steel in accordance with welding thermal cycle, welding technique, structure, and properties of welded joints
}

Anatoliy Zavdoveev, Massimo Rogante, Valeriy Poznyakov, Mark Heaton, Philippe Acquier, Hyoung Seop Kim, Thierry Baudin, Valeriy Kostin

\section{To cite this version:}

Anatoliy Zavdoveev, Massimo Rogante, Valeriy Poznyakov, Mark Heaton, Philippe Acquier, et al.. Development of the PC-GMAW welding technology for TMCP steel in accordance with welding thermal cycle, welding technique, structure, and properties of welded joints. Reports in Mechanical Engineering, 2020, 1 (1), pp.26-33. 10.31181/rme200101026z . hal-03010575

\section{HAL Id: hal-03010575 \\ https://hal.science/hal-03010575}

Submitted on 17 Nov 2020

HAL is a multi-disciplinary open access archive for the deposit and dissemination of scientific research documents, whether they are published or not. The documents may come from teaching and research institutions in France or abroad, or from public or private research centers.
L'archive ouverte pluridisciplinaire HAL, est destinée au dépôt et à la diffusion de documents scientifiques de niveau recherche, publiés ou non, émanant des établissements d'enseignement et de recherche français ou étrangers, des laboratoires publics ou privés. 


\title{
Development of the PC-GMAW welding technology for TMCP steel in accordance with welding thermal cycle, welding technique, structure, and properties of welded joints
}

\author{
Anatoliy Zavdoveev', Massimo Rogante ${ }^{2}$, Valeriy Poznyakov', Mark Heaton ${ }^{3}$, Philippe Acquier ${ }^{4}$, \\ Hyoung Seop Kim ${ }^{5}$, Thierry Baudin', Valeriy Kostin ${ }^{1}$ \\ ${ }^{1}$ Paton Electric Welding Institute of NAS, Bozhenko, Kiev, Ukraine, e-mail: avzavdoveev@ gmail.com \\ ${ }^{2}$ Rogante Engineering Office, Contrada San Michele 61, Civitanova Marche, Italy, e-mail: main@ roganteengineering.it \\ ${ }^{3}$ ANT, Advanced Nano Technology, Park West business park, Dublin, Ireland, e-mail: mark.heaton@ antsltd.com> \\ ${ }^{4}$ ADDUP France, Cébazat, France, e-mail: philippeacquier@yahoo.fr \\ ${ }^{5}$ Pohang University of Science and Technology, Department of Materials Science and Engineering, Pohang, Korea, e- \\ mail: hskim@postech.ac.kr \\ ${ }^{6}$ Université Paris-Saclay, CNRS, Institut de chimie moléculaire et des matériaux d'Orsay, Orsay, France, e-mail: \\ thierry.baudin@universite-paris-saclay.fr
}

\begin{tabular}{|c|c|}
\hline Article Info & ABSTRACT \\
\hline Article history: & \multirow{8}{*}{$\begin{array}{l}\text { In this paper, the effect of the welding thermal cycle (WTC) on the structure } \\
\text { and properties of the S460M steel heat affected zone (HAZ) metal has been } \\
\text { studied. In particular, the changes in the mechanical properties vs the HAZ } \\
\text { metal cooling rate in the } 600 \div 500{ }^{\circ} \mathrm{C} \text { temperature range was studied for } \\
\text { S460M model samples, heat-treated in accordance with WTCs. The results } \\
\text { from the experimental data refers to the static strength, ductility, and impact } \\
\text { toughness values at the level of the base metal, as well as to structural } \\
\text { changes in the seam. The weld metal and HAZ welded joints of S460M steel, } \\
\text { made by pulsed arc welding, have shown adequately high resistance to brittle } \\
\text { fracture, and at } 20 \% \text { greater strength. Thus, based on the obtained results, it } \\
\text { is recommended to apply pulse-current gas metal welding of the thermo- } \\
\text { mechanical cold processing steel instead of conventional welding. }\end{array}$} \\
\hline Received March 17, 2020 & \\
\hline Revised May 7, 2020 & \\
\hline Accepted May 20, 2020 & \\
\hline Keywords: & \\
\hline PC-GMAW & \\
\hline TMCP steel & \\
\hline High strength steels & \\
\hline Microstructure & \\
\hline
\end{tabular}

Copyright (C) 2020 Regional Association for Security and crisis management and European centre for operational research. All rights reserved.

\section{Corresponding Author:}

Massimo Rogante,

Rogante Engineering Office.

Email: main@ roganteengineering.it

\section{Introduction}

Developments in the modern construction and energy industries demands metal beam fabrication capable of withstanding a lot of physical force. In the case of the steel industry, there is a wish to also increase reliability (Bilik et al., 2013; Lobanov, 1993; Nazarov et al., 2014; Odesskiy et al., 2011; Poznyakov et al., 2012; Ragu Natan et al., 2015; Tilkin et al., and 1983; Ufuah \& Ikhayere, 2013). This effect could be reached by adopting new high strength steels having a yield stress higher than $390 \mathrm{MPa}$. The structural steel of such a class of strength is used in the building industry, bridge construction, wind energy, and also railway transport (Odesskiy et al., 2011; Ufuah \& Ikhayere, 2013). The application of high strength steels gives an opportunity to reduce the overall weight up to $80 \%$ in comparison with steels of $300 \mathrm{MPa}$ strength (Bilik et al., 2013). In the modern industry, two approaches are used to develop steels with improved mechanical characteristics (increased level of strength). The first consists of the application of alloying elements. This method leads to a 
significant rise in the price of manufactured rods. An alternative path for the alloying procedure is thermomechanical cold processing (TMCP). Such a kind of steel is the high strength low alloyed (HSLA) steel grade S460M (490 MPa level of strength, EN:10025-4), micro-alloyed with Nb and V. Its mechanical characteristics are conditioned by a refined structure, obtained by TMCP.

During any construction employing HSLA steels, the problem of their weldability arises (Ragu Natan et al., 2015). A number of definitions for weldability exist, but in our consideration, we hold with the following one: weldability is the ability of the welded metal to form monolithic joints with comparable properties to the base metal. It is commonly known that during a welding process, the HAZ metal is subjected to the influence of high temperature (up to the melting point at the fusion line); thus, structural changes occur that can result in changes in the mechanical properties of the metals (Poznyakov et al., 2012). In this connection, and in the current work, we are considering the effect of the welding thermal cycle (WTC) on the structure and properties of HAZ metal of S460M steel. Based on these results, we have proposed pulse-current gas metal arc welding (PC-GMAW) technology to create sound welded joints.

\section{Materials and methodology}

For our experimental needs a structural steel called S460M was selected that had a thickness of $16 \mathrm{~mm}$. The chemical composition is reported in Table 1 while the mechanical properties are in Table 2.

Table 1. The S460M steel as received: chemical composition, wt. \%

\begin{tabular}{cccccccccc}
\hline $\mathrm{C}$ & $\mathrm{Si}$ & $\mathrm{Mn}$ & $\mathrm{Cr}$ & $\mathrm{Ni}$ & $\mathrm{V}$ & $\mathrm{Nb}$ & $\mathrm{Al}$ & $\mathrm{S}$ & $\mathrm{P}$ \\
\hline 0.15 & 0.23 & 1.3 & 0.09 & 0.019 & 0.01 & 0.05 & 0.025 & 0.013 & 0.017 \\
\hline
\end{tabular}

Table 2. The S460M steel as received: mechanical properties

\begin{tabular}{cccc}
\hline $\mathrm{YS}$ & $\mathrm{UTS}$ & $\delta_{5}$ & $\psi$ \\
$\mathrm{MPa}$ & $\mathrm{MPa}$ & $\%$ & $\%$ \\
\hline 480 & 600 & 27 & 58 \\
\hline
\end{tabular}

For the criteria of welding thermal cycle (WTC), the cooling rate (W6/5) was chosen from metal heated up to $1300{ }^{\circ} \mathrm{C}$ in the temperature range of $600 \div 500{ }^{\circ} \mathrm{C}$ (interval of minimum equilibrium of austenite).

The results were used to find the cooling rates at which the metal strength of the HAZ, ductility, and toughness indices decreased in comparison to the regulated requirements for welded joints. The change in the mechanical properties in relation to the HAZ metal at a cooling rate in the $600 \div 500{ }^{\circ} \mathrm{C}$ temperature range, were studied using $120 \times 12 \times 12 \mathrm{~mm}^{3}$ model samples. These were heat-treated in accordance with welding thermal cycles at the MCP-75 unit (Sarjevskiy \& Sazonov, 1981). The heat treatment process was the following.

The samples, crossed by current, were firstly heated to temperatures in the range $1200 \div 1300{ }^{\circ} \mathrm{C}$, which are typical for the coarse grain heat affected zone (CGHAZ) of welded joints. The heating rate was in the range $150 \div 170{ }^{\circ} \mathrm{C} / \mathrm{s}$, which corresponds to the conditions of metal heating in the zone of thermal influence during arc welding processes. The samples were held at such temperatures for approximately 2 seconds, and then they were forcibly cooled.

For a static tensile test of the steel, cylindrical samples (3 for each cooling rate) having a 6 mm diameter across the working part were mechanically manufactured (type II in accordance with GOST 6996-96, equal to ISO 6892:1998 norm). The tests were carried out at ambient temperature.

For the impact toughness determination, the Charpy impact tests were carried out at the temperatures of $+20,-20$, and $-40{ }^{\circ} \mathrm{C}$ (type IX GOST $6996-96$, i.e., $10 \times 10 \times 55 \mathrm{~mm}^{3}$ with V-notch, according to the ASTM A370 norm).

Gas metal arc welding ( $\mathrm{Ar}+18 \% \mathrm{CO} 2)$ of $16 \mathrm{~mm}$ steel S460M joints with a V-shaped opening of the G3Si1 solid cross-section of $1.2 \mathrm{~mm}$. Root passages, when welding this steel were performed on a copper substrate. The welding using the traditional process (steady-state arc) was performed for the modes: $I_{w}=180$ $200 \mathrm{~A}, \mathrm{Uarc}=26 \mathrm{~V}, \mathrm{Vw}=15-18 \mathrm{~m} / \mathrm{h}$. The modes for the automated pulsed arc welding were as follows: $I_{a v}=$ 220-240 A, Uarc $=26-28 \mathrm{~V}, \mathrm{Vw}=14-21 \mathrm{~m} / \mathrm{h}$. Here:

$$
I_{a v}=\frac{I_{\text {pulse }} t_{\text {pulse }}+I_{\text {pause }} t_{\text {pause }}}{t_{\text {pulse }}+t_{\text {pause }}},
$$

where $I_{\text {pulse }}=450 \mathrm{~A}, I_{\text {pause }}=160 \mathrm{~A} t_{\text {pulse }}$, and $t_{\text {pause }}$ are the pulse duration and pause, respectively. It should be noted that, in addition to the average current of the arc-arc welding, that the effective current of the arc-arc welding also applies: 


$$
I_{e f}=\sqrt{(1) \times I_{\text {pause }}^{2}+I_{\text {pulse }}^{2}},
$$

where $\delta=$ duty cycle. Thus, given the above-mentioned parameters of pulsed-arc welding, $I_{e f}-300 \mathrm{~A}$ is almost $25 \%$ higher than the Iav.

\section{Results and discussion}

The structure and mechanical properties of the as-received metals are the following. TMCP hardened steel S460M (strength class $440 \mathrm{MPa}$ ) was manufactured according to the EN 10025-4:2007. Due to the thermomechanical rolling and controlled cooling in the temperature range of $900-700{ }^{\circ} \mathrm{C}$ (TMCP) in S460M steel, a ferrite-pearlite, banded structure with a Vickers hardness of $195 \mathrm{HV}$ was formed (see Figure 1).

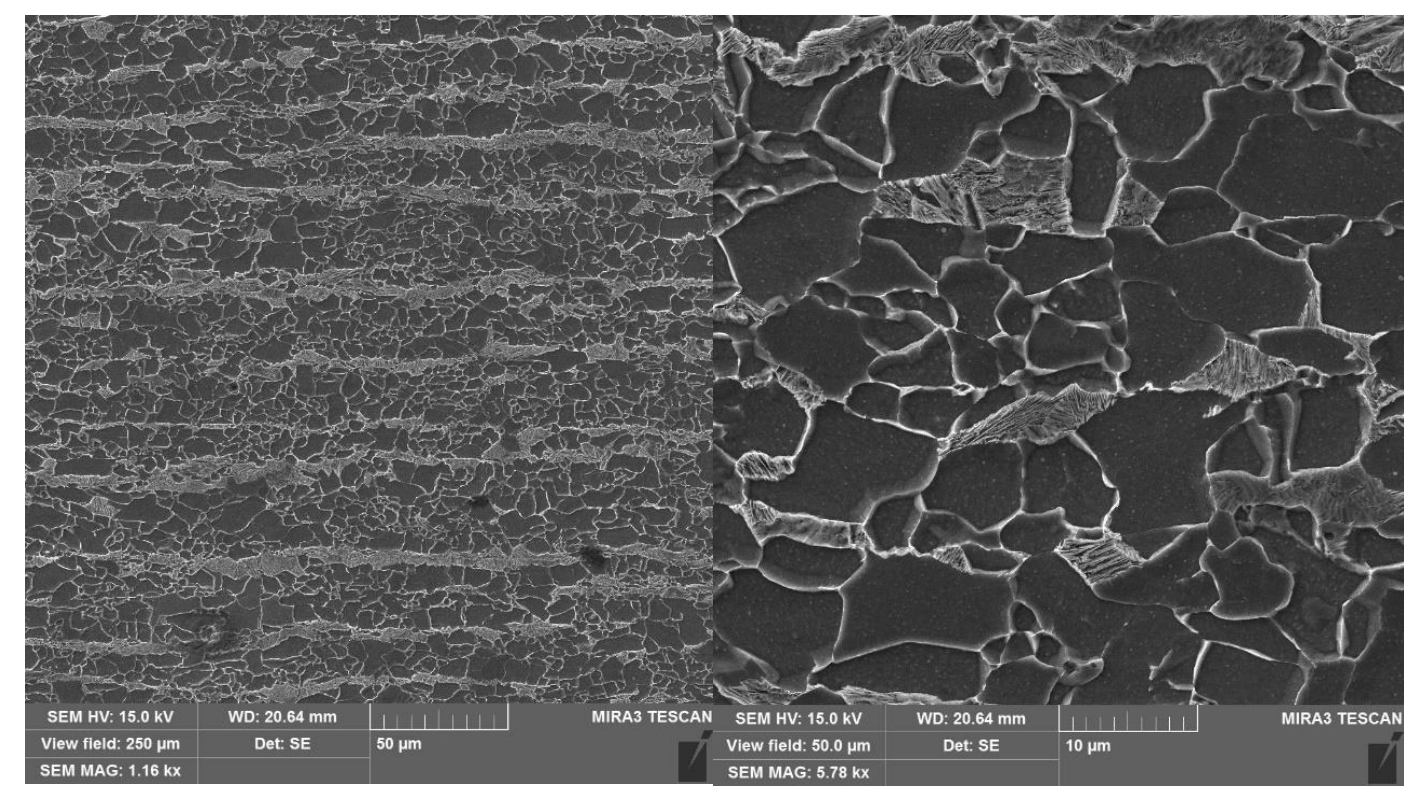

Figure 1. Microstructure of the S460M steel as it was received.

Slight contamination was observed in the form of non-metallic inclusions such as silicates, aluminosilicates, sulphides, and oxysulfide. The fracture toughness of the S460M steel is significantly higher than the standard values of $\mathrm{KCV}_{-40} \geq 34 \mathrm{~J} / \mathrm{cm}^{2}$, even at a test temperature of $-60{ }^{\circ} \mathrm{C}\left(\mathrm{KCV}_{-60}=76 \mathrm{~J} / \mathrm{cm}^{2}\right)$.

The dependencies characterizing the changes in the strength and ductility parameters in the simulated metal of the HAZ of S460M steel under the influence of WTC are shown in Figures 2 and 3.

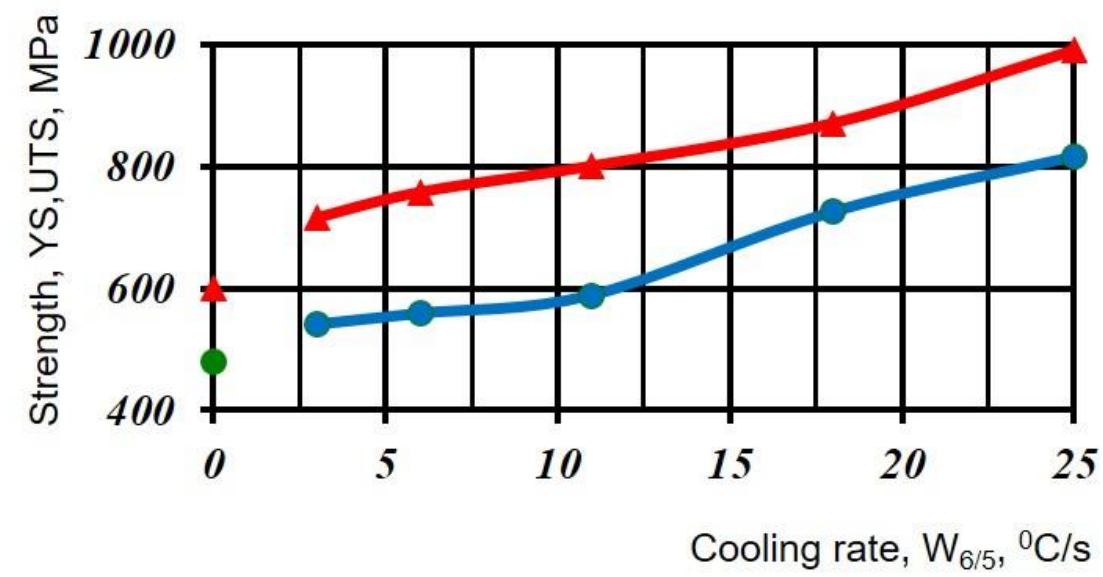


Figure 2. Yield (green) and ultimate tensile (red) strength in dependence on cooling rate for the S460M steel.

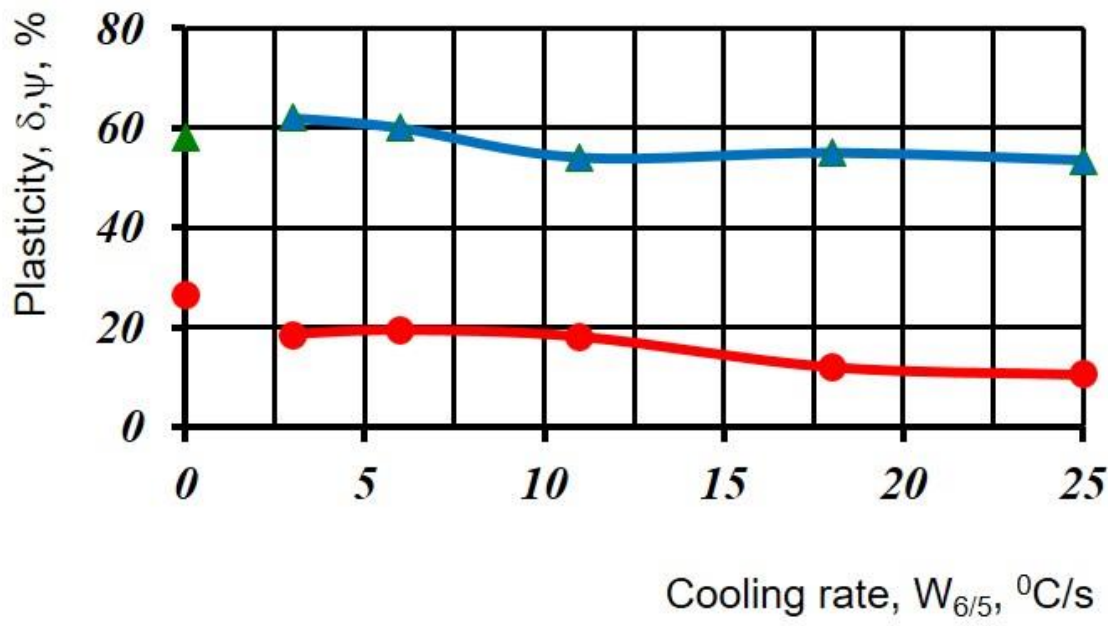

Figure 3. Relative reduction (green) and relative elongation (red) in dependence on the cooling rate for the S460M steel.

The results indicate that with the change in the cooling rate from 3 to $25^{\circ} \mathrm{C} / \mathrm{s}$ in the temperature range $600-500{ }^{\circ} \mathrm{C}(\mathrm{W} 6 / 5)$ the indices of the HAZ metal strength increases in comparison to the initial state. That is to say, YS from 490 to $810 \mathrm{MPa}$ and UTS from 600 to $1000 \mathrm{MPa}$. At the same time, the plastic properties of the simulated HAZ metal deteriorates in comparison to the initial state. This is especially true concerning the indices of the relative elongation, which are reduced by 2.5 times, while the relative elongation is reduced by $15-20 \%$.

In the impact bending tests of samples with a V-notch, the impact toughness of the S460M steel HAZ metal decreases with respect to the base metal (see Figure 4).

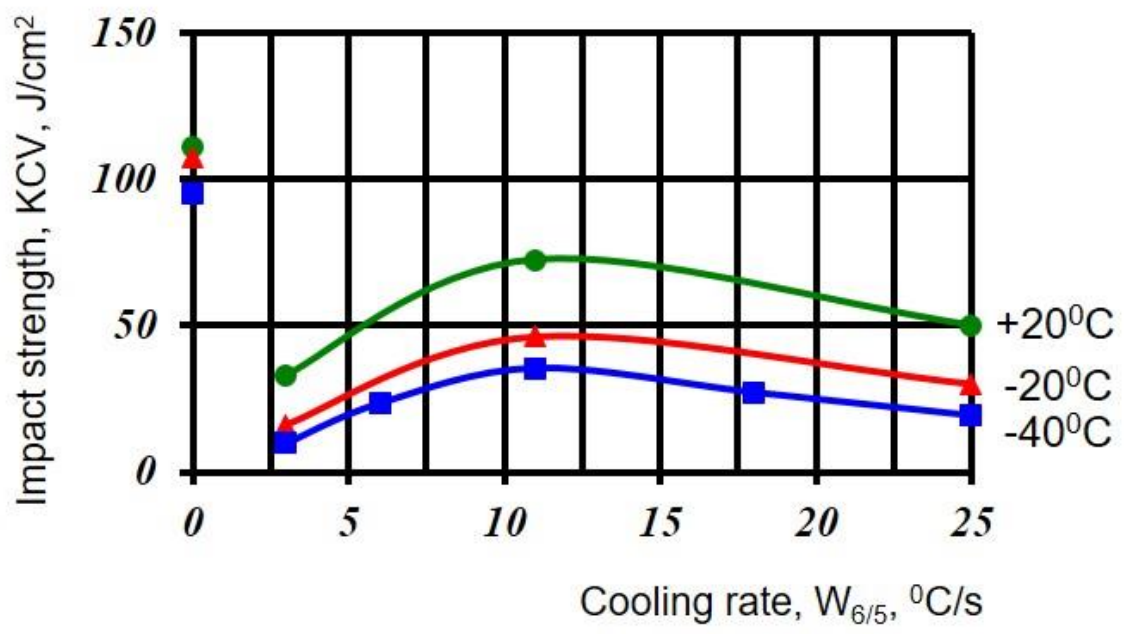

Figure 4. Impact toughness dependence on cooling rate for the S460M steel.

The most significant decrease in the $\mathrm{KCV}$ value is from 4 to 9 times in the samples that cooled at a rate of $\mathrm{W}_{6 / 5}=3{ }^{\circ} \mathrm{C} / \mathrm{s}$ (from 111 to $33 \mathrm{~J} / \mathrm{cm}^{2}$ at the test temperature of $+20{ }^{\circ} \mathrm{C}$, from 109 to $15 \mathrm{~J} / \mathrm{cm}^{2}$. This was at a temperature of $-20^{\circ} \mathrm{C}$, and from 95 to $10 \mathrm{~J} / \mathrm{cm}^{2}$ at a temperature of $-40{ }^{\circ} \mathrm{C}$.

With an increase in the cooling rate to $10{ }^{\circ} \mathrm{C} / \mathrm{s}$, they increase to $\mathrm{KCV}_{-40}=27 \mathrm{~J} / \mathrm{cm}^{2}$, and then decrease somewhat. At $\mathrm{W}_{6 / 5}=25{ }^{\circ} \mathrm{C} / \mathrm{s}$ they result in: $\mathrm{KCV}_{+20}=50 \mathrm{~J} / \mathrm{cm}^{2} ; \mathrm{KCV}-20=30 \mathrm{~J} / \mathrm{cm}^{2}$; and $\mathrm{KCV}_{-40}=20$ $\mathrm{J} / \mathrm{cm}^{2}$ (for comparison to the impact toughness of the $\mathrm{S} 460 \mathrm{M}$ steel are within $95-110 \mathrm{~J} / \mathrm{cm}^{2}$ at test temperatures from $+20^{\circ} \mathrm{C}$ to $-40^{\circ} \mathrm{C}$ ). 
Such changes in the mechanical properties of the S460M steel HAZ metal are due to various structural transformations in the range of the studied cooling rates. This is evidenced by the results from metallographic studies, which showed that a structure consisting of different morphological forms of ferrite and a small amount of perlite is formed in the CGHAZ metal of the $\mathrm{S} 460 \mathrm{M}$ steel, when at a cooling rate of $\mathrm{W}_{6 / 5}=3{ }^{\circ} \mathrm{C} / \mathrm{s}$ (see Figure 5).

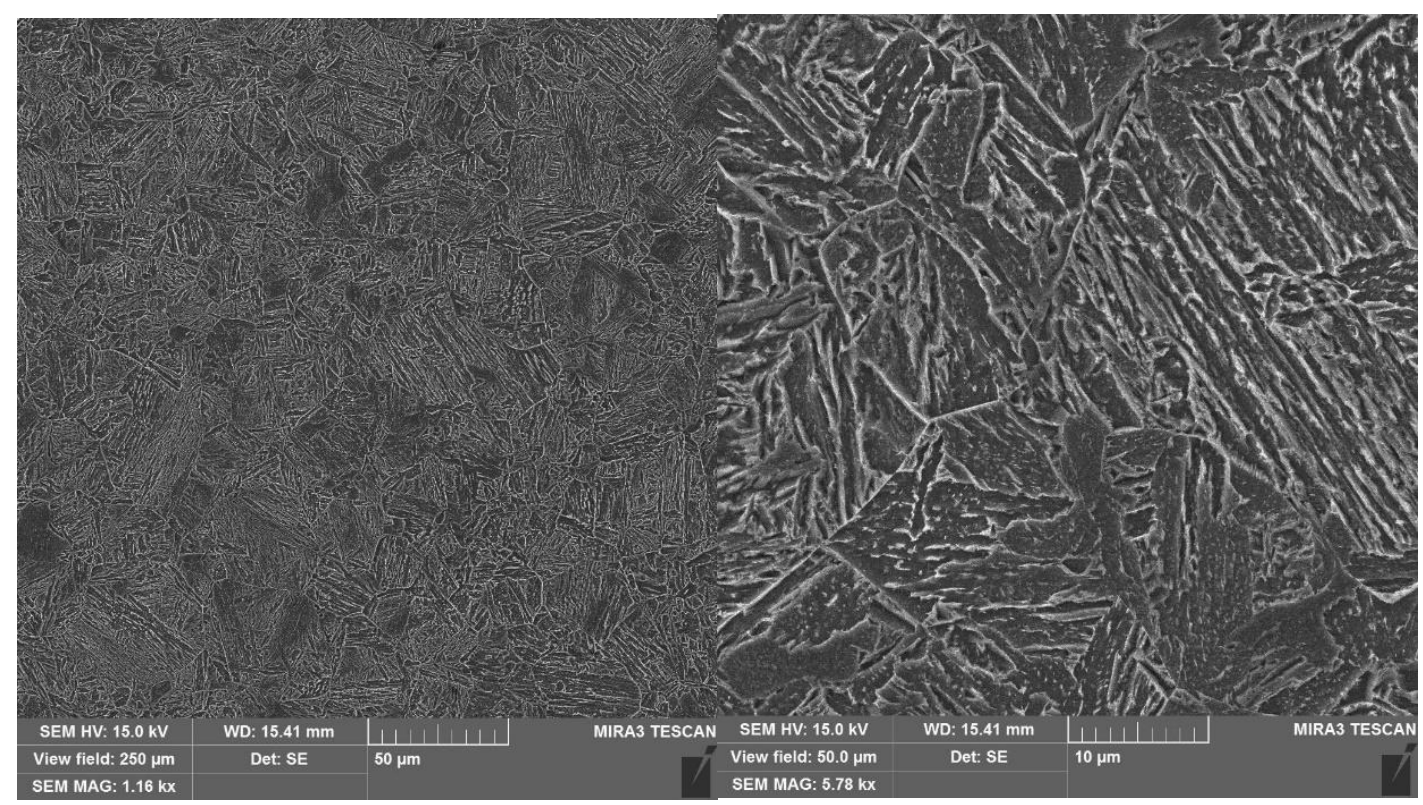

Figure 5. Microstructure of CGHAZ of the S460M steel; $\mathrm{W}_{6 / 5}=25^{\circ} \mathrm{C} / \mathrm{s}$.

The hardness of such metal is $240 \mathrm{HV}$, and the bands of its structure, as observed before the thermal cycle, disappears completely. An equiaxial ferrite-pearlite having a bainitic component is formed with a finely dispersed structure having an increase in $\mathrm{W} 6 / 5$ to $10{ }^{\circ} \mathrm{C} / \mathrm{s}$. The grain size, in this case, slightly increases to $15 \mathrm{mkm}$, but the hardness is almost unchanged even though the strength indicators increase by $\approx 100 \mathrm{MPa}$.

With a further increase in the cooling rate to $\mathrm{W} 6 / 5=25^{\circ} \mathrm{C} / \mathrm{s}$ in the imitated CGHAZ metal, a structure is formed consisting of a mixture of upper and lower bainite and a small amount of martensite and ferrite. Due to this fact, the hardness of the metal rises to a $\mathrm{HV}=2800 \mathrm{MPa}$, which in turn leads to an increase in the indices of its static strength and a drop in its plastic properties.

Metallographic studies of the structure of S460M steel welded joints (Figure 6) revealed that, when welding an arc, which heats and melts steadily in the joint, a ferrite structure having various modifications (polygonal, polyhedral, and coarse-grain) is formed. 


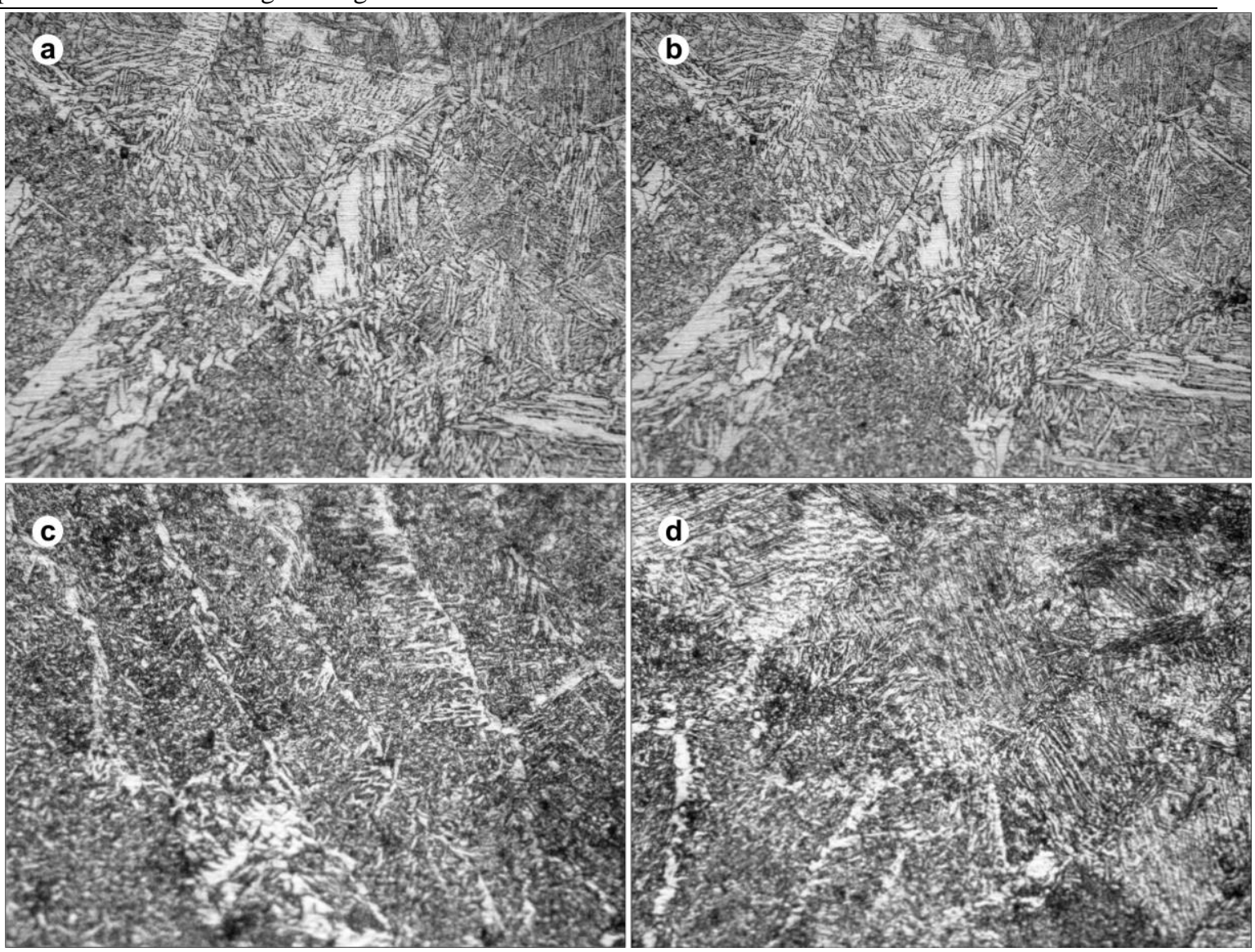

Figure 6. Microstructure of the weld metal (a, c) and HAZ (b, d) of S460M steel, made by traditional arc $(\mathrm{a}, \mathrm{b})$ and pulse-arc $(\mathrm{c}, \mathrm{d})$ welding $(\mathrm{x} 500)$.

The Vickers hardness of such a structure is in the range from $1950 \mathrm{MPa}$ to $2030 \mathrm{MPa}$. The microstructure of the large grain area of the thermal impact zone consists of a mixture of upper and lower bainite. The Vickers hardness of the HAZ section reaches $2730 \mathrm{MPa}$. In the area of the fine grains of the HAZ, there is a structure of mainly upper bainite. The hardness of this section of the HAZ decreases to $2600 \mathrm{MPa}$. In the area of incomplete recrystallization of the HAZ, ferrite and perlite are formed near the bainite section. This significantly reduces the hardness to $2130-2260 \mathrm{MPa}$.

Under pulse-arc welding, the microstructure of the weld metal differs significantly from the microstructure of the weld metal as made by arc welding. That is to say that the needle ferrite plates (from 1 to 3 microns) are significantly ground, and the number of polyhedral ferrites is reduced from 5 to $10 \%$. The selection of polygonal ferrite (from $3-10 \mu \mathrm{m}$ ), which is located along the boundaries of primary austenitic grains, becomes significantly narrower. Such changes in the microstructure leads to an increase in the joint hardness up to $2420 \mathrm{MPa}$. In the area of large HAZ grain, there is a predominantly bainitic structure that has a small percentage (from 3 to 5\%) of hard martensite. The hardness of this section of the HAZ increases accordingly from 3250 - $3340 \mathrm{MPa}$. The structure of the area of fine-grain HAZ consists of a mixture of upper and lower bainites (2650 - $2810 \mathrm{MPa})$. On the site of incomplete recrystallization of HAZ, there is perlite and ferrite, which significantly reduces the hardness of the metal, according to Vickers to 2320 - 2400 $\mathrm{MPa}$.

Such differences in the microstructure are caused by the peculiarities of the WTC flow during pulsed arc welding, namely, the rate of cooling of the metal at the HAZ sections, which are heated to temperatures of $1000{ }^{\circ} \mathrm{C}$ and higher than during the steady-state arc welding process.

The study of the hardness (Figure 7) of the welded joints showed that in the case of PC-GMAW, the hardness level in the weld metal was $20 \%$ higher than the hardness of the weld metal performed by arc welding. 


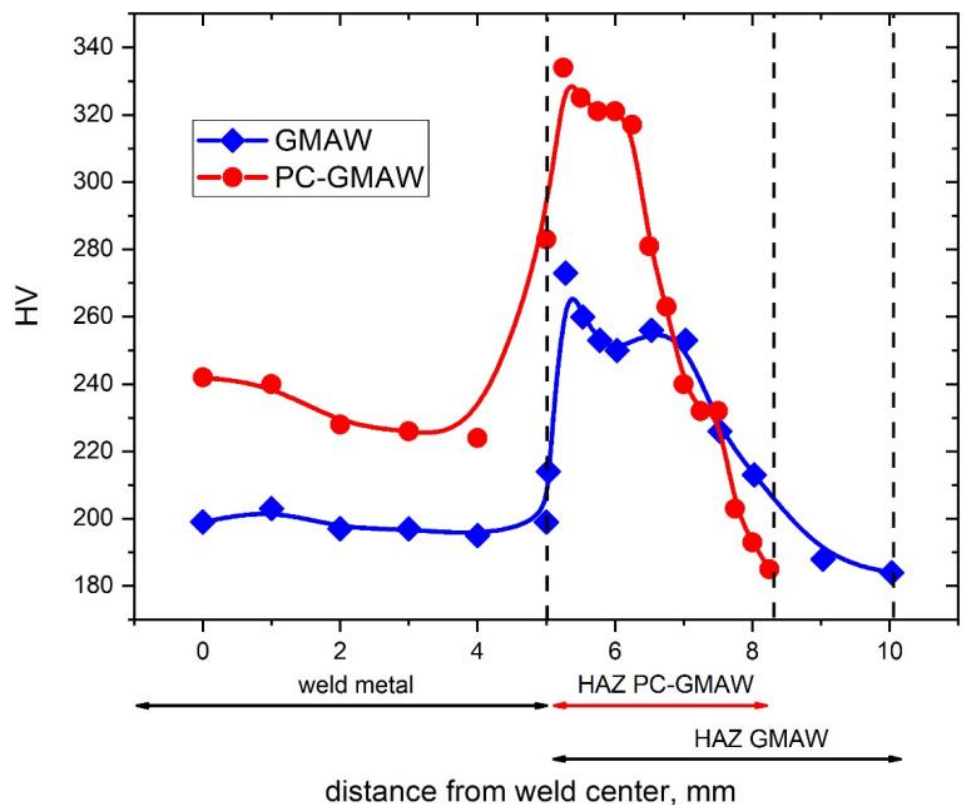

Figure 7. Hardness of welded joints of steel S460M.

The mechanical properties of welded joints are given in Table 3.

Table 3. Mechanical properties of welded steel joints of the S460M under different welding methods.

\begin{tabular}{|c|c|c|c|c|c|c|c|}
\hline & $\begin{array}{l}\text { Welding } \\
\text { technique }\end{array}$ & $\begin{array}{l}\text { YS, } \\
\mathrm{MPa}\end{array}$ & $\begin{array}{l}\text { UTS, } \\
\mathrm{MPa}\end{array}$ & $\delta$ & $\psi$ & $\begin{array}{c}\mathrm{KCV}_{+20} \\
\mathrm{~J} / \mathrm{cm}^{2}\end{array}$ & $\begin{array}{c}\mathrm{KCV}_{-40} \\
\mathrm{~J} / \mathrm{cm}^{2}\end{array}$ \\
\hline \multirow{2}{*}{ Weld } & GMAW & 477 & 586 & 28 & 73 & 215 & 100 \\
\hline & PC- GMAW & 570 & 667 & 24 & 68 & 212 & 111 \\
\hline \multirow{2}{*}{ HAZ } & GMAW & $632 *$ & $763 *$ & - & - & 149 & 150 \\
\hline & PC- GMAW & $778^{*}$ & $940 *$ & - & - & 137 & 122 \\
\hline $\mathrm{BM}$ & & 452 & 581 & 26 & 60 & 111 & 95 \\
\hline
\end{tabular}

The data presented shows that under pulsed arc welding conditions, greater strength values are achieved while maintaining the impact strength at the level of EN $10025-2 \mathrm{KCV}_{-40} \geq 25 \mathrm{~J} / \mathrm{cm}^{2}$. The resistance to brittle fracture of the welded joints made by pulsed arc welding, despite the high values of hardness, is at an adequate level due to the formation of a fine grain structure.

\section{Conclusions}

For the cooling rates in the range of $7 \leq \mathrm{W} 6 / 5 \leq 15^{\circ} \mathrm{C} / \mathrm{s}$ related to the $\mathrm{HAZ}$ metal of the $\mathrm{S} 460 \mathrm{M}$ steel samples model, the values of static strength, ductility, and impact toughness is retained at the same level as the base metal.

The analysis of the experimental data showed that at the PC-GMAW, due to the change of the WTC (an increase of the cooling rate in the temperature range $>1000^{\circ} \mathrm{C}$ ), a crushed structure is formed in the seam in comparison with the GMAW. It also transpired that in the HAZ, the quenching structures are formed. In this case, the cooling rate of the HAZ metal in the temperature range $600-500{ }^{\circ} \mathrm{C}$ decreases almost 1.5 times. This allowed a reduction in the width of the $\mathrm{HAZ}$ by $40 \%$. As a result of the tests, it was found that the weld metal and HAZ welded joints of S460M steel, made by pulsed arc welding, had a sufficiently high resistance to brittle fracture in the studied temperature range, and up-to a $20 \%$ greater strength. 
Acknowledgment: Financial supports through NAS of Ukraine project (\#113) for young scientists "Effect of thermal cycle of welding and high temperature isothermal heating on the structure and properties of steel grade S355J2 and S460M" are acknowledged.

\section{References}

Bilik A., Kurashev R., Gorbatenko V., \& Konovalov G. (2013). Application of TMCP rolled in welded metallic constructions. Industrial construction and engineering structures, 4, 1-4.

Lobanov L.M. (editor) (1993). Welded building structures (in Russian). Naukova Dumka, Kiev, p. 415.

Nazarov, A.V., Yakushev E., Shabalov I., Morozov Yu., \& Kireeva T. (2014). Comparison of Weldability of High-Strength Pipe Steels Microalloyed with Niobium, Niobium and Vanadium. Metallurgist, 57, 911-917. https://doi.org/10.1007/s11015-014-9821-6

Odesskiy P., Molodtsov A., \& Morozov Yu. (2011). New effective low-alloyed steels for building metallic constructions. Mounting and especial works in building (in Russian), 5, 20-25.

Poznyakov V., Jdanov S., \& Maksimenko A. (2012). Structure and properties of welds made from S355J2 steel. Automat Weld, 8, 7-11.

Ragu Nathan S., Balasubramanian V., \& Malarvizhi S. (2015). Effect of welding processes on mechanical and microstructural characteristics of high strength low alloy naval grade steel joints. Def Technol, 11, 308317. https://doi.org/10.1016/j.dt.2015.06.001

Sarjevskiy V., \& Sazonov V. (1981). Equipment for thermal cycle of welding imitating based on MSR-75 machine. Automat Weld, 5, 69-70.

Tilkin M., Bolshakov V., \& Odesskiy P. (1983). Structure and properties of building steel (in Russian). Metallurgy, p. 287.

Ufuah E., \& Ikhayere J. (2013). Elevated Temperature Mechanical Properties of Butt-Welded Connections Made with High Strength Steel Grades S355 and S460M. In: Jármai K., Farkas J. (eds) Design, Fabrication and Economy of Metal Structures. Springer, Berlin, Heidelberg 407-412. https://doi.org/10.1007/978-3-64236691-8_62 